\title{
Analysis of the Serratia marcescens proBA operon and feedback control of proline biosynthesis
}

\author{
Kenji Omori, Shin-Ichi Suzuki, Yuji Imai and Saburo Komatsubara* \\ Research Laboratory of Applied Biochemistry, Tanabe Seiyaku Co. Ltd, 16-89 Kashima-3-chome, Yodogawa-ku, \\ Osaka 532, Japan
}

(Received 30 July 1990; revised 6 November 1990; accepted 19 November 1990)

\begin{abstract}
The proBA operon, coding for $\gamma$-glutamyl kinase (GK) and $\gamma$-glutamyl phosphate reductase (GPR), was cloned from the chromosome of the wild-type strain of Serratia marcescens Sr41. From our sequence data the proB (1101 bp) and pro $A(1472 \mathrm{bp})$ genes were shown to code for two proteins of $M_{\mathrm{r}} 39169$ and 44640 , respectively. Analysis of expression of the lac $Z$ structural gene fused with the proBA promoter showed that the proBA operon is not subject to proline-mediated feedback repression. Amplification of the proBA operon enabled us to determine GK activity, which was inhibited in the presence of a low concentration of $L$-proline. Comparison of the amino acid sequences of the $S$. marcescens $G K$ and GPR proteins with those of the GK and GPR proteins from $E$. coli revealed extensive similarities.
\end{abstract}

\section{Introduction}

In micro-organisms, proline is synthesized from glutamate via three enzymic reactions catalysed by $\gamma$-glutamyl kinase (GK; proB product, EC 2.7.2.11), $\gamma$-glutamyl phosphate reductase (GPR; pro A product, EC 1.2.1.41) and 1-pyrroline-5-carboxylate reductase (proC product, EC 1.5.1.2) (Adams \& Frank, 1980). Feedback control mechanisms and genetic backgrounds for proline biosynthesis have been extensively studied in Escherichia coli $\mathrm{K} 12$. GK, the first enzyme in this pathway, is subject to feedback inhibition by proline (Baich, 1969). The proB and proA genes constitute the pro operon, which is distant from the proC gene on the chromosome (Bachmann \& Low, 1980). Proline-hyperproducing strains of Serratia marcescens $\mathrm{Sr} 41$ have been constructed by selection of mutants resistant to proline analogues and cloning of the relevant genes (Sugiura et al., 1985a; Takagi et al., 1985). One of these strains, carrying the $d p r-1$ mutation, was selected for resistance to dehydroproline and has been reported to produce more than $60 \mathrm{~g}$ of L-proline $1^{-1}$ in a fermentation medium containing sucrose and urea (Sugiura et al., 1985b). Transductional analysis indicated that the $d p r-1$ mutation is located in the proBA region. However, there have been few

Abbreviations: AK, aspartokinase; GK, $\gamma$-glutamyl kinase; GPR, $\gamma$-glutamyl phosphate reductase; ORF, open reading frame.

The nucleotide sequence data reported in this paper have been submitted to GenBank, and have been assigned the accession number X53086. findings on genetic and enzymic profiles of the regulation of proline biosynthesis in $S$. marcescens.

This paper deals with the analysis of the gene structure of the wild-type proBA operon of $S$. marcescens and, in addition, the study of the feedback control of proline biosynthesis in this bacterium.

\section{Methods}

Strains, plasmids and media. The strains and plasmids used are listed in Table 1. E. coli JM109 was used as a host for the construction of plasmids. The rich medium used was LB (Davis et al., 1980) and the minimal medium of Davis \& Mingioli (1950) was modified by omitting sodium citrate and increasing the glucose concentration to $0.5 \%$. Required L-amino acids were used at a concentration of $1 \mathrm{~mm}$. Antibiotics were added at the specified concentrations: kanamycin (Km), $200 \mu \mathrm{g} \mathrm{ml}^{-1}$; ampicillin (Ap), $200 \mu \mathrm{g} \mathrm{ml}^{-1}$.

Genetic methods. DNA manipulations were carried out according to standard procedures (Maniatis et al., 1982). Transformation of E. coli or $S$. marcescens was done as described by Takagi \& Kisumi (1985).

In vitro transcription-translation analysis. The prokaryotic cell-free coupled transcription-translation system from Amersham (DeVries \& Zubay, 1967) was employed for labelling proteins encoded by plasmids. Plasmid DNA (0.4 $\mu \mathrm{g})$, prepared by $\mathrm{CsCl}$ density gradient centrifugation, was added to the reaction mixture $(5 \mu \mathrm{l})$ containing L${ }^{[35}$ S $]$ methionine, according to the protocol of the manufacturer. After $60 \mathrm{~min}$ incubation at $37^{\circ} \mathrm{C}$, SDS-PAGE of ${ }^{35} \mathrm{~S}$-labelled proteins was carried out as described by Laemmli (1970). Labelled polypeptide bands were visualized by autoradiography.

DNA sequence analysis. The DNA sequence of the plasmid containing the cloned $S$. marcescens proBA genes was determined by the 
Table 1. Bacterial strains and plasmids

\begin{tabular}{|c|c|c|}
\hline Strain or plasmid & $\begin{array}{l}\text { Genotype or } \\
\text { phenotype* }\end{array}$ & Source or reference \\
\hline \multicolumn{3}{|l|}{ E. coli $\mathrm{K} 12$} \\
\hline JM109 & thi & Yanisch-Perron et al. (1985) \\
\hline HB101 & proA2 leu thi & Boyer \& Roulland-Dussoix (1969) \\
\hline ME6198 & $\Delta($ lac-pro $)$ leuB bio thi & National Institute of Genetics, Japan \\
\hline \multicolumn{3}{|l|}{ S. marcescens $\mathrm{Sr} 41$} \\
\hline 8000 & Wild-type & Matsumoto et al. (1975) \\
\hline TT392 & $\mathrm{Nuc}^{-} \mathrm{r}^{-} \mathrm{Ap}^{\mathrm{s}} \mathrm{Km}^{\mathrm{s}}$ & Takagi \& Kisumi (1985) \\
\hline SP 103 & putA & Sugiura et al. (1985a) \\
\hline \multicolumn{3}{|l|}{ Plasmids } \\
\hline pBR322 & $A p^{r} T c^{r}$ & Bolivar et al. (1977) \\
\hline pLG339 & $\mathrm{Km}^{\mathrm{r}} \mathrm{Tc}^{\mathrm{r}}$ & Stocker et al. (1982); derived from pSC101 \\
\hline $\left.\begin{array}{l}\text { pHSG298 } \\
\text { pHSG299 }\end{array}\right\}$ & $\mathrm{Km}^{\mathrm{r}} \operatorname{lac} Z \alpha$ & Takeshita et al. (1987) \\
\hline pMC1871 & Tc $\operatorname{lac} Z$ & Shapira et al. (1983) \\
\hline pKK $223-3$ & $\mathrm{Ap}^{\mathrm{r}} \mathrm{P} t a c r r n B T_{1} T_{2}$ & $\begin{array}{l}\text { Brosius \& Holy (1984); expression } \\
\text { vector bearing a tac promoter and } r m B T_{1} T_{2} \\
\text { terminator }\end{array}$ \\
\hline pUC18 & $\mathrm{Ap}^{\mathrm{r}} \operatorname{lac} Z \alpha$ & Yanisch-Perron et al. (1985) \\
\hline pWP102 & pBR322::proBA & This study \\
\hline pWP142 & pBR322::proBA & This study \\
\hline pWP144 & pBR322::proB & This study \\
\hline pLGlacZ1 & pLG339::lacZ & This study \\
\hline pWPL10 & pLG339::proB-lacZ & This study \\
\hline pUPE18 & pUC18:: $r n B T_{1} T_{2}$ & This study \\
\hline pUTWP18 & pUPE18::Ppro & This study \\
\hline
\end{tabular}

* Symbols used for relevant genotypes and phenotypes are as follows: $\mathrm{Nuc}^{-}$, no production of extracellular nuclease; $\mathrm{r}^{-}$, defect of a host restriction enzyme; Ppro, promoter of the proBA genes.

dideoxy chain termination method (Sanger et al., 1977) with templates prepared from DNA subcloned in pHSG298 and pHSG299. Ordered deletion subclones were obtained by unidirectional digestion (YanischPerron et al., 1985). The DNA chains were labelled with $\left[\alpha^{-32} \mathrm{P}\right] \mathrm{dCTP}$ $\left(400 \mathrm{Ci} \mathrm{mmol}^{-1} ; 15 \mathrm{TBq} \mathrm{mmol}^{-1}\right)$. Analysis of sequence data was performed using the computer program GENETYX (Software Development, Japan), and the protein sequence databases NBRF-PDB (National Biomedical Research Foundation) and swISs-PROT (European Molecular Biology Laboratory).

$R N A$ analysis by primer extension. pro operon $\mathrm{mRNA}$ was analysed by reverse-transcriptase-directed primer extension using a synthetic 20mer oligonucleotide, 5'-CAATTTCACAACCAATGTCT-3', complementary to a region from position +54 to +73 of the mRNA (De la Peña \& Zasloff, 1987). To facilitate the detection of extended products, a pUC-derived, high-copy-number plasmid (pUPE 18), which contains the transcription terminator of the $r m B$ gene, was used. Unless otherwise stated, blunt-ending was achieved by digestion with mung bean nuclease. pUPE18 was constructed by cloning a blunt-ended $0.9 \mathrm{~kb} E c o \mathrm{RI}-S c a \mathrm{I}$ fragment, containing the $r m B T_{1} T_{2}$ terminator and the $5^{\prime}$ region of the ampicillin resistance gene from pKK223-3, into the $P v u I I$ and $S c a I$ sites of pUC18, thus restoring resistance to ampicillin. A blunt-ended BamHI-Sall fragment, containing the proBA promoter region of pWP142, was cloned into the $S m a I$ and $S a I$ sites of pUPE18 to give pUTWP18. RNA extracted from recombinant cells of $S$. marcescens TT392 containing PUTWP18 was thus enriched for the transcript lacking the $3^{\prime}$ region of the proBA coding sequence. RNA was purified using the glass-beads/hot-phenol extraction procedure (Hinnebusch \& Fink, 1983; Peoples et al., 1988) and $20 \mu \mathrm{g}$ of RNA was mixed with $20 \mathrm{pmol}$ of $5^{\prime}$ end $\alpha^{-32} \mathrm{P}$-labelled primer. The mixture was denatured at $80{ }^{\circ} \mathrm{C}$ in $50 \mathrm{~mm}$-PIPES/KOH (pH 6.4), $0.4 \mathrm{M}-\mathrm{NaCl}, 1 \mathrm{~mm}$ EDTA and $50 \%$ formamide for $15 \mathrm{~min}$ and chilled on ice. PrimerRNA hybridizations were carried out at $20^{\circ} \mathrm{C}$ for $16 \mathrm{~h}$. After ethanol precipitation, DNA-RNA hybrids were extended at $42{ }^{\circ} \mathrm{C}$ for $60 \mathrm{~min}$ in $50 \mathrm{~mm}$-Tris/ $\mathrm{HCl}$ (pH 8.3), $100 \mathrm{~mm}-\mathrm{KCl}, 10 \mathrm{~mm}-\mathrm{MgCl}_{2}, 1 \mathrm{~mm}$-DTT, $1 \mathrm{mM}$ each of dGTP, dATP, dCTP, dTTP, 0.5 units of human placental ribonuclease inhibitor (Promega) and 22 units of RAV reverse transcriptase (Takara Shuzo). The products were fractionated on an $8 \%$ polyacrylamide sequencing gel. A dideoxy sequencing ladder was run in parallel for size comparison.

Analysis of proB-lac $Z$ expression. The regulation of the proBA promoter was examined by using a promoter analysis plasmid. Amplification of the regulatory site of the gene in a high-copy-number plasmid might cause abnormal expression of the gene because of the absence of its repressor or activator. For this reason we constructed a low-copy-number promoter analysis plasmid pLGlacZ1, by cloning a blunt-ended (filled in) $3.0 \mathrm{~kb} \mathrm{BamHI}$ fragment from pMC1871, carrying the promoterless $l a c Z$ structural gene, into the filled in EcoRI and nuclease treated BamHI sites of the low-copy-number plasmid pLG339. The plasmid that carried the lacZ gene in the opposite orientation to the tet gene of pLG339 was selected as pLGlacZ1. We constructed a gene fusion by ligating the beginning of the lac $Z$ structural gene in frame with the region containing the $p r o B A$ promoter and the $\mathrm{N}$-terminus of the proB gene product. The proB-lac $Z$ gene fusion plasmid pWPL10 was constructed by cloning the blunt-ended $0.3 \mathrm{~kb} \mathrm{BamHI}-$ SaclI fragment of pWP142 into the filled in BamHI site of pLGlacZ1. The proline-oxidase-deficient mutant of $S$. marcescens, SP103, was used as a host to prevent the degradation of L-proline added to the medium (Sugiura et al., 1985a). 
Assay of enzyme activity. Cells were grown at $30^{\circ} \mathrm{C}$ in $500 \mathrm{ml}$ flasks containing $200 \mathrm{ml}$ of minimal medium. For the assay of GK activity the cells were harvested in the exponential growth phase, washed with $50 \mathrm{~mm}$-Tris/ $\mathrm{HCl}(\mathrm{pH} \mathrm{7.2)}$ containing $1 \mathrm{mM}-\mathrm{DTT}$ and disrupted by sonication. The cell extracts were desalted with a Pharmacia PD-10 column and used for the hydroxamate assay of GK activity as described by Hayzer \& Leisinger (1980). The standard assay, containing $50 \mathrm{mM}-\mathrm{L}-$ glutamate, was used. The difference between values with and without the addition of $100 \mathrm{mM}-\mathrm{L}$-proline to the reaction mixture represented the proline-inhibitable GK activity. The proline-inhibitable GK of TT392 containing pWP142 was inhibited by $100 \mathrm{mM}$-L-proline to the level of the same strain without the plasmid.

For the assay of $\beta$-galactosidase the cells were harvested in the exponential growth phase, washed with saline and resuspended in $100 \mathrm{~mm}$-sodium phosphate buffer ( $\mathrm{pH} 7 \cdot 0$ ) containing $10 \mathrm{~mm}-\mathrm{KCl}$, $1 \mathrm{mM}-\mathrm{MgSO}_{4}$ and $50 \mathrm{~mm}-2$-mercaptoethanol. After disruption by sonication, the resultant cell extracts were used for the assay of $\beta$ galactosidase. $\beta$-Galactosidase activities were measured using $o$ nitrophenyl $\beta$-D-galactoside as a substrate (Miller, 1972).

The units of GK and $\beta$-galactosidase activity were expressed as nmol products formed $\mathrm{min}^{-1}(\mathrm{mg} \text { protein })^{-1}$. Protein concentration was determined by the use of a Bio-Rad protein assay kit with bovine serum albumin as the standard protein.

\section{Results}

\section{Cloning of the wild-type proBA operon of S. marcescens}

The proBA operon of $S$. marcescens 8000 , a wild-type strain of $\mathrm{Sr} 41$, was cloned into the BamHI site of pBR322 by selecting $\mathrm{Pro}^{+}$clones derived from $E$. coli $\mathrm{HB} 101$ (proA) and the resultant plasmid was denoted pWP102 (Fig. 1). This plasmid complemented the proBA mutation carried by $E$. coli ME6198. Southern analysis demonstrated that the insert DNA came from the $S$. marcescens chromosome and that there was no rearrangement of DNA (data not shown). The restriction map of the inserted DNA fragment agreed with that of the insert of pYI333, which was previously reported to carry the mutant-type pro genes from a proline-producing strain (Takagi et al., 1985). Plasmid pWP142 contains a $2.9 \mathrm{~kb}$
NcoI-MluI fragment carrying the proBA region, inserted into the BamHI and EcoRI sites of pBR322. This plasmid complemented the proBA mutations carried by strain ME6198 and the pro $A$ mutation carried by strain HB101. Plasmid pWP144, constructed by deleting a $0.7 \mathrm{~kb}$ EcoRV-MluI fragment from pWP142, did not complement the pro $A$ mutation, indicating that the $E c o$ RV site is located in the proA gene.

\section{Analysis of the pWP142-encoded proteins}

In order to determine the sizes of the pro $A$ gene products encoded by $\mathrm{pWP142}$, we used an in vitro expression system (DeVries \& Zubay, 1967) and SDS-PAGE (Fig. 2). Unique ${ }^{35}$ S-methionine-labelled proteins of $M_{\mathrm{r}} 44000$ and $M_{\mathrm{r}} 39000$ were detected for pWP142, whereas similar proteins were not detected for pBR322.

\section{Nucleotide sequence of the $2.9 \mathrm{~kb} D N A$ fragment carrying the proBA operon}

Figs 1 and 3 show the strategy for the DNA sequencing and the complete nucleotide sequence of the $2.9 \mathrm{~kb} \mathrm{NcoI-}$ MluI fragment of pWP102. Analysis of this nucleotide sequence for potential protein coding regions revealed two tandem open reading frames (ORFs). The first ORF extends from an ATG initiation codon at position 182 to a TAA termination codon at position 1283, and consists of 1101 nucleotides. The second ORF starts 10 nucleotides downstream of the termination codon of the first ORF and extends for 1472 nucleotides to a termination codon at position 2546. Putative Shine-Dalgarno (SD) sequences, AGAA and AGGA, have been identified upstream of the two initiation codons, respectively. $M_{\mathrm{r}}$ values of the two gene products were calculated on the basis of the predicted amino acid sequences. The first and second ORFs code for polypeptides of 367 and 417 amino acids with deduced $M_{\mathrm{r}}$ values of 39169 and 44640 ,

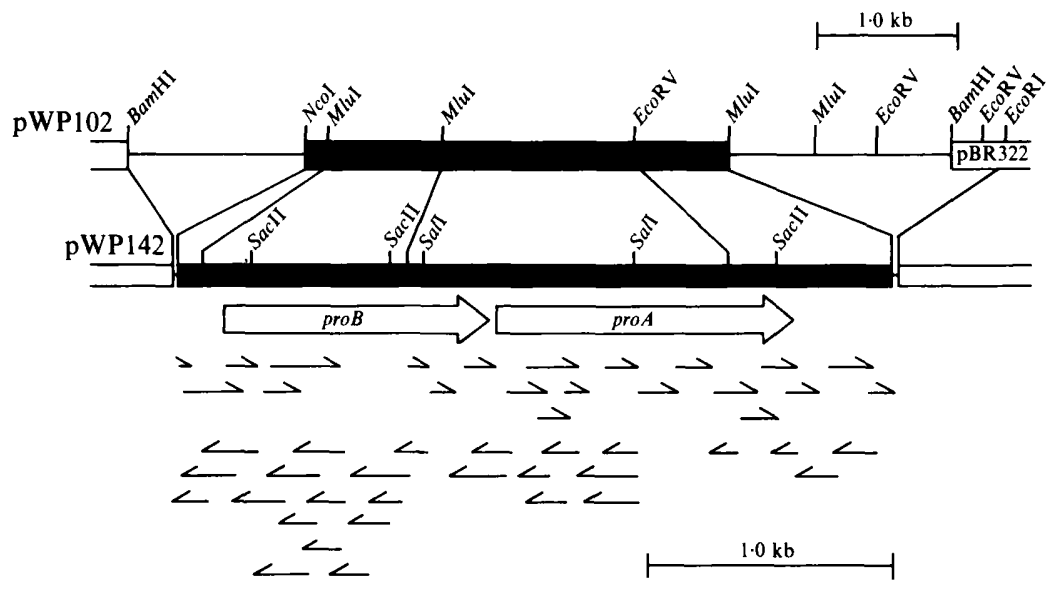

Fig. 1. Restriction maps of the proBA plasmids pWP102 and pWP142, and sequencing strategy for the proBA region. $S$. marcescens DNA was digested with $B a m H I$ and a $5.8 \mathrm{~kb}$ DNA fragment was cloned into BamHI-digested pBR322, resulting in pWP102. For the construction of pWP142, a $2.9 \mathrm{~kb} \mathrm{NcoI}-\mathrm{MluI}$ fragment (filled in) from pWP102 was cloned into the filled in BamHI and EcoRI sites of pBR322. The thin arrows indicate the strategy used to obtain the complete nucleotide sequence of the $N c o I-M / u I$ fragment. Open arrows show the ORFs of the proBA operon. 


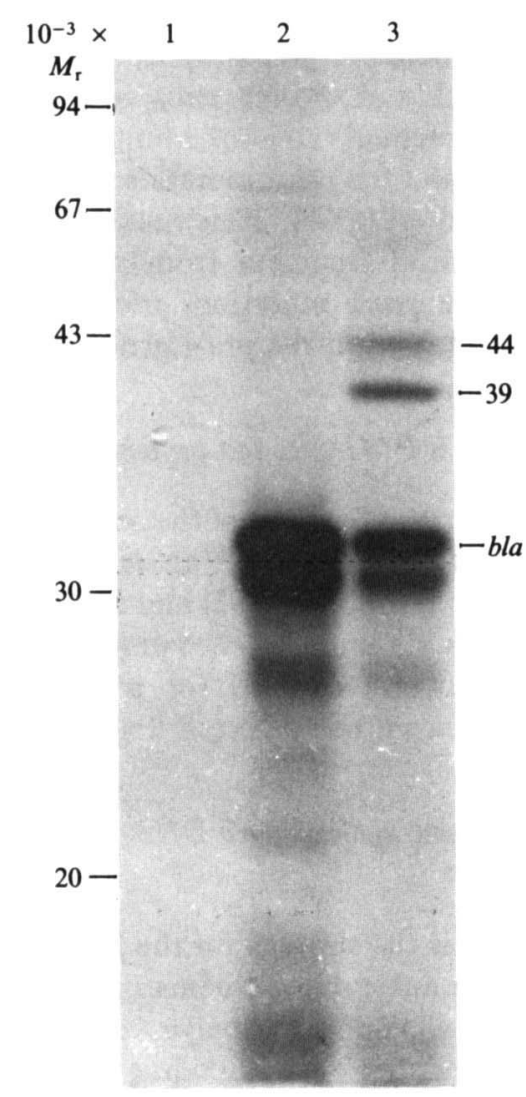

Fig. 2. Analysis of polypeptides encoded by recombinant plasmid pWP142 carrying the proBA genes. Plasmid-specified polypeptides were produced in S-30 cell-free extract from $E$. coli. The ${ }^{35} \mathrm{~S}$-labelled polypeptides synthesized in vitro were analysed by SDS-PAGE and visualized by autoradiography. Lane 1, no plasmid; lane 2, pBR322; lane 3, pWP142. The migration of protein standards is indicated on the left-hand side. bla indicates $\beta$-lactamase encoded by the plasmids used.

respectively. These values are consistent with those obtained from the in vitro expression system analysis above. Based on these data, together with the complementation results described above for pWP144, in which a part of the second ORF was deleted, we concluded that the first and second ORFs represent the proB and pro $A$ genes, respectively. The dyad symmetry of the T-rich cluster which follows the proA gene suggests a strong stem-loop structure with a $10 \mathrm{bp}$ stem and a 6 base loop. This sequence is similar to the $\rho$-independent terminators from E. coli (Rosenberg \& Court, 1979). These observations confirmed that the proBA genes of $S$. marcescens form a single operon. The short distance between the two genes is supplementary evidence for a single operon.
Transcription initiation site of the proBA promoter region

To locate the transcription initiation site of the proBA operon, we used primer extension analysis. We subcloned the promoter region of the proBA operon into a pUC-derived vector and obtained pUTWP18, which produces the $5^{\prime}$ region of the proBA mRNA but does not affect cell growth because of lack of the structural genes. A synthetic oligonucleotide complementary to the $5^{\prime}$ region of the mRNA of the proB gene was synthesized as a primer. Three distinct extended products were observed after the reverse transcriptase reaction using the RNA from $S$. marcescens TT392 containing pUTWP18 (Fig. 4). The proBA gene is transcribed from the first start site located at the $T$ residue at position 142. The two sequences, TTGGCA and TACAAA, are located 35 and $10 \mathrm{bp}$ upstream of this position, respectively. These sequences were thus confirmed to constitute the promoter of the pro operon (Fig. 3). The putative -35 region (TTGGCA) and its flanking sequences contain a dyad symmetry centred on positions 107 and 108 .

\section{Transcriptional control of the proBA operon}

We constructed a proB-lac $Z$ fusion plasmid, pLGlacZ1, and analysed the activity of $\beta$-galactosidase in $S$. marcescens SP103 containing this plasmid to examine the transcriptional regulation of the proBA operon. $\beta$ Galactosidase activity in this strain was not influenced by the addition of L-proline to the culture medium (Table 2). In addition, osmotic stress caused by the addition of $\mathrm{NaCl}$ to the culture medium did not affect proB-lacZ expression.

\section{Feedback inhibition of $G K$}

There have been few reports on feedback control of the level of inhibition of enzyme activities involved in proline biosynthesis in $S$. marcescens. This has probably been due to the failure to detect GK activity in strains previously examined. We used $S$. marcescens TT392 containing the high-copy-number proBA recombinant plasmid, pWP142, to measure the proline-inhibitable GK activity. L-Proline completely inhibited the activity at concentrations greater than $0.04 \mathrm{~mm}$ and inhibited it by $50 \%$ at $0.016 \mathrm{~mm}$ (the absolute value corresponding to

Fig. 3 (on facing page). Nucleotide sequence of the $S$. marcescens proBA operon and its flanking regions. The deduced amino acid sequences of the proB-and proA-encoded proteins are given under the nucleotide sequence. Only the restriction sites used for subsequent experiments are shown. The possible ribosome binding sites (SD) and putative -10 and -35 sequences are underlined. The transcription start site is indicated by stars and the direction of transcription by an arrow. A region of dyad symmetry, centred on nucleotide positions 107 and 108, and a potential transcription termination sequence (positions 2573-2598) are indicated by arrows. The ORF upstream of the proBA promoter, discussed in the text, is boxed. 
NCOI

1 CCATGGAACTGGGGCTGGAACCCGCCGACGATTTCAAAGAAAAACTGATCAAACTCTCCGCQTGACCCCGTTTGACCACGTATTGTGCTGATTTCGCGTT - -Me tGluLeuGly LeuGIuProAlaAspAspPheLysG1uLysLeuI leLysLeuSerAla * * *

$\longrightarrow \stackrel{M 1 U \mathrm{I}}{\longrightarrow}-1+1 \quad$ proB

$101 \overrightarrow{\text { GTGCCTGTTGGCATAACGCGTCTCTCCTGTTACAAAGACCTTTGCACTCTTCTTCTCATCATTACACACGGCAGAAATACT ATGAACGGCAGCCAGACAT }}$

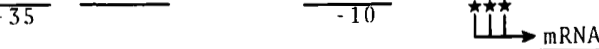

SD

MetAsnGIySerGInThrL 200

TCTGAACCGCGCCCACATCGTCGAATTGGTGCGCCAGTGCGCGCAGCAACACGC 1 TGGTTGTGAAATTGGGACCAGCGT SacI I

301 CGCGGGCCACCGCATTGTCATCGTCACCTCCGGCGCCATCGCCGCCGGGCGCGAACACCTGGGCTACCCCGAGCTGCCCGCCACCATCGCTTCCAAGCAG

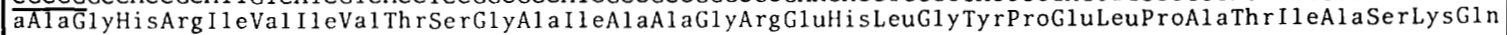

CTGCTGGCAGCGGTGGGGCAGAGCCGGCTGATCCAGCTGTGGGAACAGCTGTTCTCCATTTACGGTATCCACGTCGGGCAGATGCTGCTGACGCGCGCCG

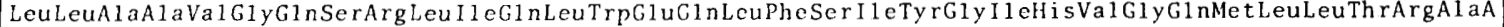

ATCTGGAAGACCGCGAGCGCTTCCTCAACGCGCGCGATACCATGACGGCGCTGCTGGACAACCGCATCGTGCCGGTAATCAATGAGAACGACGCCGTCGC spLeuGluAspArgGluArgPheLeuAsnA1 a ArgAspThrMetThrAlaLeuLeuAspAsnArg I 1 eVal ProVal I leAsnGluAsnAspAlaValAl

CACCGCCGAAATCAAGGTGGGCGACAACGATAACCTGTCGGCACTGGCGGCCATTCTGGCCGGGGCCGACAAACTGCTGCTGCTGACCGATCAGCAGGGC

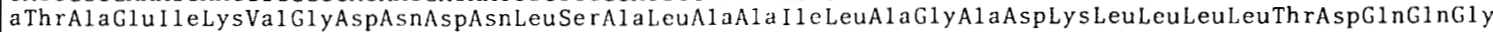
CTCTACACCGCCGATCCGCGCAACAATCCGCAGGCCGAACTGATCCGTGAAGTGCACGGCATCGACGACGCGCTGCGCGCCATCGCCGGCGACAGCGTCT LeuTyrThrAl aAsp ProArgAsnA snProGlnAl aGluLeuI l eArgGluValHisGly I leAspAspAl a LeuArgAla I leAl aGl yAspSerVal SacII

801

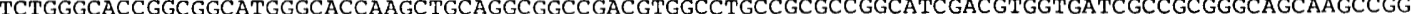

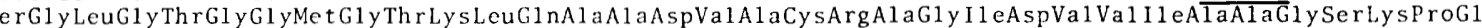
$M l u I$

901 CGTGGTGGCGGACGTGATCGAAGGCAAACCGGTGGGCACCCGTTTCCACGCGTTGGAAACCCCGCTGGAAAACCGCAAGCGCTGGATCTTTGGCGCGCCA

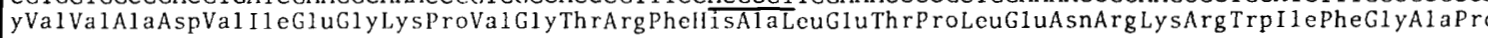
01 Sal

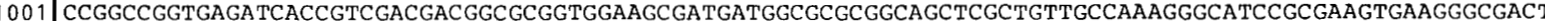
ProAlaGlyGluIl eThrValAspAspGiyAlaValGluAlaMe MetAlaArgGiySerSerLeuLeuProLysG1y II eArgG1uVa1LysG1yAspP

1101 TCTCGCGCGGCGAAGTGATCCGTATCCGCAACCTGACGGGGCGCGATCTGGCGCACGGCGTCAGCCGCTACAACAGCGACGCGATGCGCATGATCGCCGG heSerArgGlyGluVal I I eArg I l eArgAsnLeuTh rGlyArgAspLeuAlaH isG1 yVal SerArg TyrAsnSerAspAl aMetArgMet I 1 eAlaG1

1201 GCACCACTC

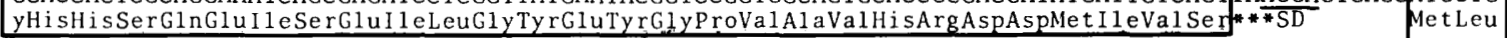

1301 GAGCAGATGGGGAAGGCCGCCAAGCAGGCCTCCTGGCAGCTGGCGGTGCTGAGCACGGCGAAGAAGAATCAGGTGCTGTCGGTGATGGCCGACAGGCTGG

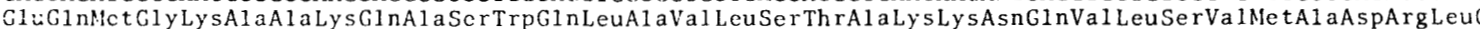
AAGCCAACAGTGAAGCGATCCTGCTGGCGAATGAACAAGACATGGCGCAGGCGCGCGCCACCGGCATGAGCGAAGCGCTGCTCGATCGCCTGTTGCTGAC luAl a AsnSerGluAl a I 1 e Leu LeuAl aAsnGluG 1 nAspMetAl aGlnAl a ArgAla ThrGlyMet SerGluAl aLeuLeuAspArg LeuLeuLeuTh

1501 CCCGGCGCGGCTGGCGGCGATCGCCAACGACGTGCGCCAGGTGTGCCGCCTGAACGATCCGGTCGGCCACGTGCTGGACGGCAACCTGCTGGACAGCGGG rProAlaArgLeuAlaAl a I eAl aAsnAspValArgG1nValCysArgLeuA snAspProValGlyHisValLeuAspG1 yAsnLeuLeuAspSe rGly CTGAAGCTGGAGCGCCGGCGGGTGCCGCTCGGCGTGATCGGCGTGATTTACGAGGCGCGGCCGAACGTCACCATCGACGTCGCCAGCCTGTGCCTGAAAA LeuLysLeuGluArgArgArgVal ProLeuGl yVal I l eGlyVal I l eTyrGluAlaArgProAsnVal Thr I leAspValAlaSe rLeuCy sLeuLysT CCGGCAACGCAGTGATCCTGCGCGGCGGTAAAGAGACGCACAACACCAACCAGGCGACGGTGAAAGTGATCCAGCAGGCGTTGGAACAGTGTGGCCTGCC

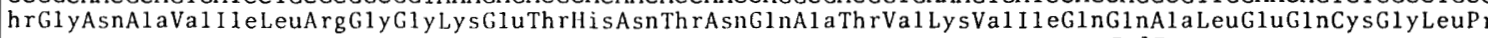
SaII

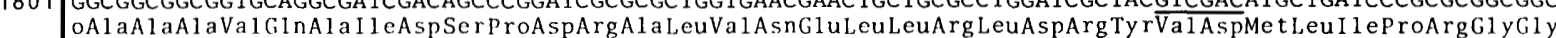

1901 GCCGGCCTACACAAGCTGTGCCGCGAGCAATCGACCATCCCGGTGATCACCGGCGGCATCGGCGTGTGCCATACCTATGTGGATGCCGACGTTGATTTCG

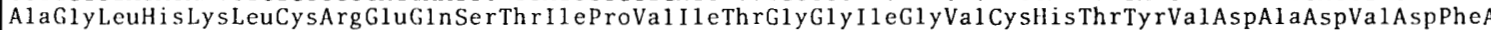

CCTGCCGGCGCTGAGCGCCAAAATGGCGGCGGCGGGCGTGACGCTGCACGCGGCGGAAAACGCGCTGCCGCTGCTGCAGGGCGGCCCGGCGACGGTGGTG e Leu ProAl a LeuSerAl a LysMe tAlaAlaAlaGlyVal Th rLeuH isAlaAlaGluAsnAl a LeuProLeuLeuGlnGl yGlyProAla ThrValVal ECORV

2201 CCGGTGAACGCGGAGGATTACGACGACGAATGGCTGTCGCTGGATCTGAACGTGCTGCTGGTGGACGATATCGATCAGGCCATCGATCACATCCGCACCC ProVal AsnAlaGluAspTyrAspAspG1uTrpLeuSerLcuAspLeuAsnValLeuLeuVal AspAspIleAspGlnAla I leAspHis I leArgThrH AcCoci isGlyThrAsnH isSerAspAlaI l eLeuThrArgSerLeuSerSerAlaGluli isPheValArgAlaValAspSerSerAlaVal TyrValAsnAlaSe SaCII

2401 CACCCGCTTCACCGACGGCGGCCAGTTCGGCTTGGGCGCTGAAGTGGCGGTGAGCACCCAGAAACTGCACGCCCGCGGCCCGATGGGCCTGGACGCGCTG rThrArgPheThrAspGlyGlyGlnPheGly LeuGlyAlaGluValAlaVal SerThrG1nLysLeuHisAlaArgG1yProMetGlyLeuAspAlaLeu

2501 ACCACCTACAAGTGGATTGGCTACGGCGACGATCTGGTGCGTAGOTAAGGCCGCATTACGGTCATAAAGAGGTCAGGGCGCACCATGCTGCGCCCTGATT 2600 ThrThrTyrLysTrpIleGlyTyrGlyAspAspLeuValArgSer* * *

2601 TTTTTTGCAGCGTAGCTGCAGTGCGGCTGTTTGCAAAACAACCAAACGCCCCGGCGGCTATTGACTCATTTCGCGCGCAGGTCTACCTTGTTCAACGCAC 2700 2701 TTCCGGCTTGCCCCGCAGGCCCGGCTCGATGCCGATATAGCTCAGTTGGTAGAGCAGCGCATTCGTAATGCGAAGGTCGTAGGTTCGACTCCTATTATCG 2800 2801 GCACCATTTCAAGTTTCACTGCCTTCCTTAGTAAAAATACGCAGCACTGGCGTCTGCAACGCTTGCGGTTGATATTTCTGCTTATCGCTATGTGGCAATA 2900 2901 TGCTGCAAGGTATAATACAAACGCGT 


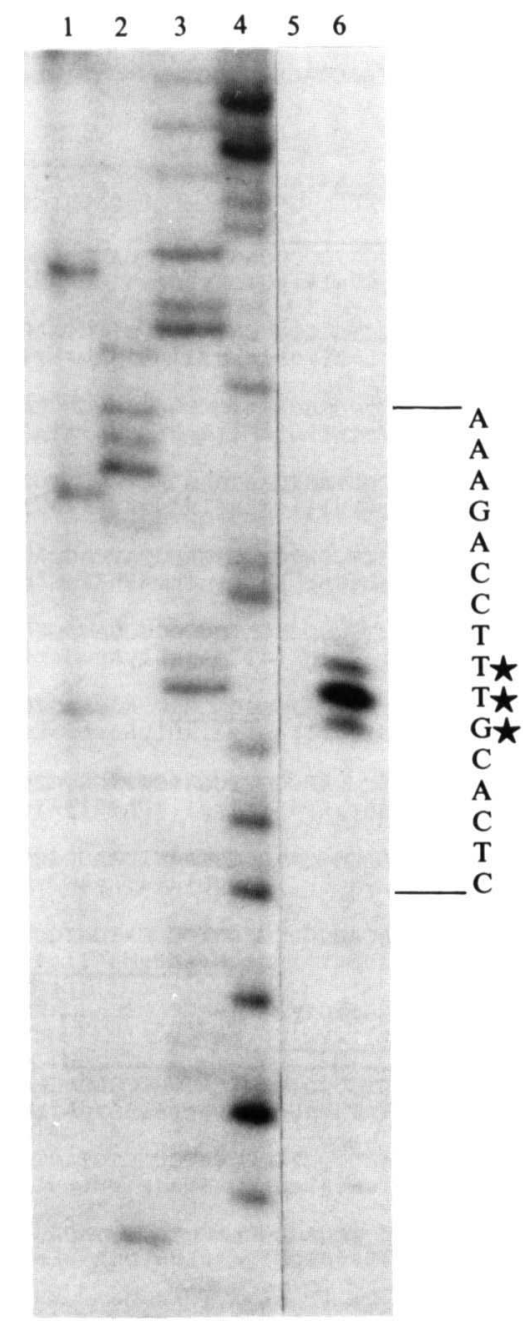

Fig. 4. 5'-End mapping of mRNA from the proBA locus by primer extension analysis. The extended products are shown alongside the dideoxy sequencing products primed by the same primer on the coding strand for size comparison. Lane 1, C; lane 2, T; lane 3, A; lane 4, G; lane $5,{ }^{32} \mathrm{P}$-labelled primer; lane 6 , extended products. The three most likely endpoints of the extension reaction are indicated by stars on the non-coding strand shown on the right-hand side. The ${ }^{32} \mathrm{P}$-labelled primer cannot be seen in the part of the gel shown (lane 5).

Table 2. Levels of $\beta$-galactosidase activity of proB-lacZ fusions in $S$. marcescens grown in modified minimal medium supplemented with L-proline or $\mathrm{NaCl}$

\begin{tabular}{lrrrrr}
\hline \hline & \multicolumn{5}{c}{ Specific activity of $\beta$-galactosidase (units)* } \\
\cline { 2 - 6 } & \multicolumn{4}{c}{ L-Proline (mM) } & NaCl (mM) \\
\cline { 2 - 6 } Strain (plasmid) & 0 & 1 & 10 & 100 & 400 \\
\hline SP103(pLG339) & $<10$ & $<10$ & $<10$ & $<10$ & $<10$ \\
SP103(pLGlacZ1) & 54 & 46 & 45 & 44 & 120 \\
SP103(pWPL10) & 470 & 460 & 490 & 500 & 400 \\
\hline \hline
\end{tabular}

* Units were expressed as nmol product formed $\min ^{-1}$ (mg protein) $)^{-1}$.

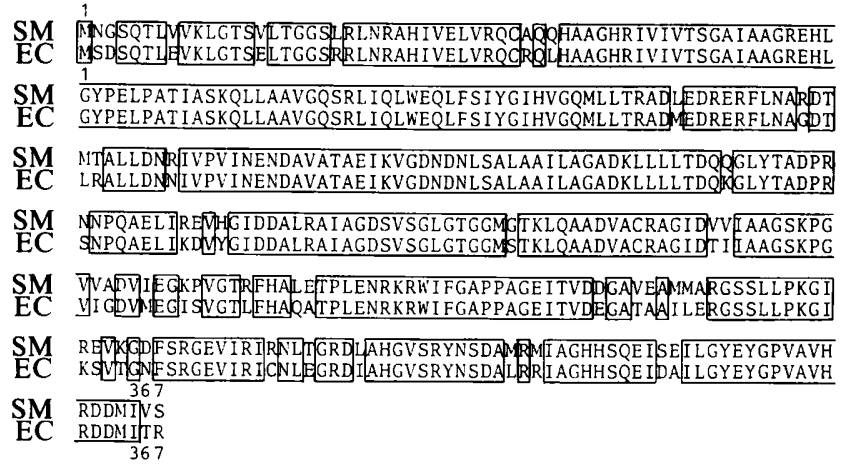

Fig. 5. Comparison of the predicted amino acid sequence of the $S$. marcescens GK with that of the $E$. coli GK. The entire amino acid sequences of $S$. marcescens GK (SM; this work) and E. coli GK (EC; Deutch et al., 1984; Csonka et al., 1988) are presented in the one-letter code. Identical residues are indicated by boxed regions.

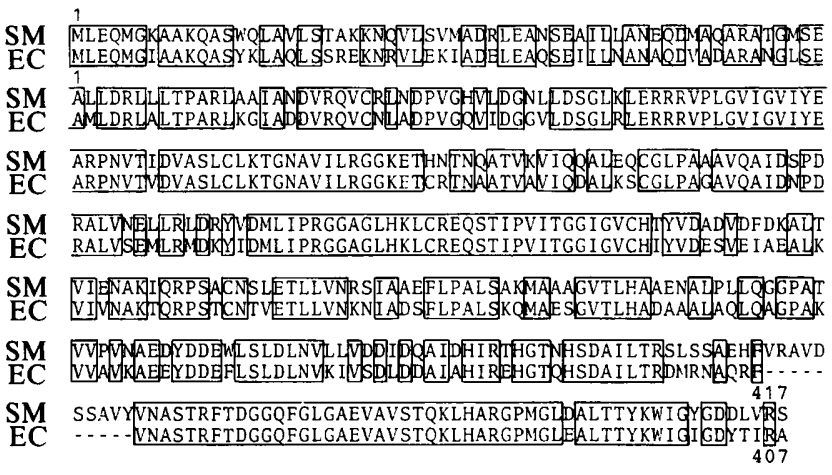

Fig. 6. Comparison of the predicted amino acid sequence of the $S$. marcescens GPR with that of the E. coli GPR. The entire amino acid sequences of $S$. marcescens GPR (SM; this work) and E. coli GPR (EC; Deutch et al., 1984; Csonka et al., 1988) are presented in the one-letter code. Identical residues are indicated by boxed regions. To maximize homology, 10 gaps were introduced into the E. coli GPR sequence.

$100 \%$ was 8.3 units of specific activity). Thus, feedback inhibition of the first enzyme in proline biosynthesis was demonstrated in $S$. marcescens.

\section{Discussion}

The proB and pro $A$ genes, encoding GK and GPR, respectively, constitute a single operon in $S$. marcescens as they do in $E$. coli. Nucleotide sequence analysis has revealed that the structure of this operon in $S$. marcescens is similar to that in E. coli. Comparison of the proB and proA products of $S$. marcescens with those of $E$. coli demonstrated $88 \%$ and $74 \%$ homology, respectively, based on the predicted amino acid sequences (Figs 5 and 6). There is no difference between the two bacteria in the 


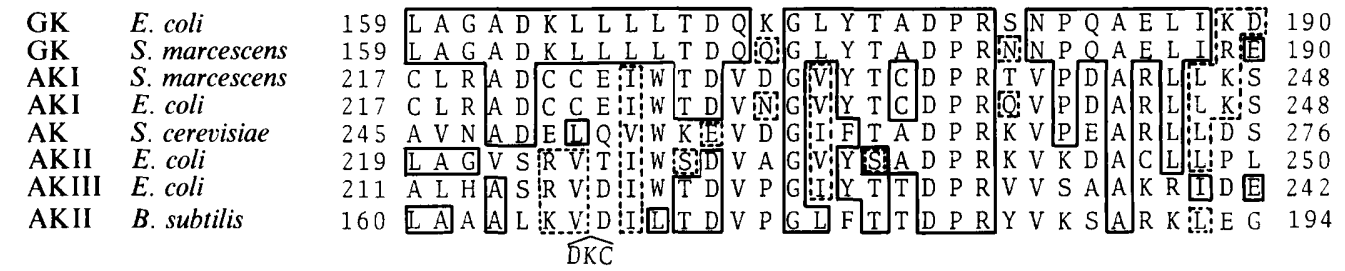

Fig. 7. Comparison of the amino acid sequences of homologous regions in GK and AK enzymes (AKI, AKII and AKIII). Partial amino acid sequences of GK and AK enzymes from S. marcescens (GK, this study; AK, our personal data), E. coli (GK, Deutch et al., 1984; AKI, Katinka et al., 1980; AKII, Zakin et al., 1983; AKIII, Cassan et al., 1986), Bacillus subtilis (AKII, Chen et al., 1987) and Saccharomyces cerevisiae (AK; Rafalski \& Falco, 1988) were compiled. Residues are presented in the one-letter code and are numbered at both ends of line. Identical and similar residues are enclosed by solid and dotted lines, respectively (accepted alternatives are I-L-VM-F, D-E, N-Q, R-K, S-T).

numbers of amino acid residues of GK. However, GPR of $S$. marcescens has an additional 10 residues in the Cterminal portion. To examine the structural features of GK, the amino acid sequence was compared with other GK and aspartokinase (AK) sequences from the database. We found that specific short regions of GK from $S$. marcescens and $E$. coli (Fig. 7) demonstrate considerable sequence similarity with regions of $\mathrm{AK}$ isoenzymes (AK, AKI, AKII and AKIII) from four micro-organisms although GK does not show any overall amino acid homology with $\mathrm{AK}$ isoenzymes. GK and $\mathrm{AK}$ produce acylphosphates, that is, $\gamma$-glutamyl phosphate and $\beta$-aspartyl phosphate, respectively. This sequence may, therefore, play an important structural role in the formation of carboxyl phosphates of amino acids. The $S$. marcescens promoter sequence is very similar to the consensus sequence of the $E$. coli promoter (Hawley \& McClure, 1983). A typical sequence for the $\rho$-independent terminator was found downstream of the proA gene.

The transcription initiation site of the proBA operon has been identified by primer extension analysis. Previously, when wild-type cells were used, it was difficult to detect extended DNA products because of the low levels of mRNA templates. The use of cells containing a high-copy-number recombinant plasmid with the cloned gene solves this problem. However, amplification of the entire gene, including the promoter and structural regions, may disturb growth of the cells and, hence, we subcloned only the promoter region into a high-copy-number plasmid. This enrichment of the mRNA enabled us to locate the transcription initiation site of the $p r o B A$ operon very accurately. The position of the proBA promoter, identified by the transcription initiation site, coincides with that predicted from the consensus sequence of the $E$. coli promoter.

The feedback control mechanism for proline biosynthesis in S. marcescens has been studied in this work. The promoter region of the proBA operon has no attenuatorlike structure, but rather a dyad symmetrical structure which might be related to gene expression. The promoter region of the E. coli proBA genes contains several inverted repeats, whereas that of $S$. marcescens has a single inverted repeat structure, which might function as a regulatory locus for the expression of the proBA genes. However, the transcription of the proBA operon was not influenced by the addition of excess proline to the culture medium as judged from data on expression of the $l a c Z$ gene fused with the proBA promoter region. These results suggest that the proBA operon from $S$. marcescens is not subject to proline-mediated feedback repression, although a previous paper reported the possibility that proline biosynthesis might be repressed by proline (Sugiura et al., 1985b). However, the findings described above coincide with those observed for $E$. coli (Deutch $e t$ al., 1984).

Amplification of the proB gene in recombinant cells has enabled us to measure GK activity in $S$. marcescens. This enzyme was found to be very sensitive to inhibition by proline. The proline concentration required to decrease the activity by $50 \%$ was $0.016 \mathrm{~mm}$ and was similar to that observed for E. coli GK (Smith et al., 1984; Dandekar \& Uratsu, 1988). Thus we concluded that, in $S$. marcescens, feedback inhibition of the first enzyme in the proline biosynthetic pathway represents the only means of regulation.

The intracellular content of proline is elevated by osmotic stress (Grothe et al., 1986). Proline is well known as an effective osmoprotectant and it has been reported that wild-type bacteria accumulate proline in response to osmotic stress. The putP, proP and proU genes are responsible for proline uptake. However, there was a possibility that expression of the proBA operon might be stimulated under conditions of high osmotic stress. Unexpectedly, a high concentration of $\mathrm{NaCl}$ did not 
affect the transcription level and, therefore, it was concluded that the proBA operon is not subject to osmoregulation.

$S$. marcescens differs from $E$. coli in the gene structure upstream of the promoter region. In $E$. coli the $p h o E$ gene lies in close proximity to the proBA promoter region on the opposite strand. In $S$. marcescens, however, an ORF was identified immediately upstream of the promoter region in the same orientation as proBA. The sequence of this ORF shows a high degree of similarity with that of the $E$. coli protein $\left(M_{\mathrm{r}} 15000\right)$ identified downstream of the phoE gene (Overbeeke et al., 1983; Nüesch \& Schümperli, 1984). This finding indicates that in $S$. marcescens the phoE gene may be located at a separate site on the chromosome.

The final goal of our research is a better understanding of the mechanisms of proline hyperproduction in $S$. marcescens mutants and we are currently determining base changes in the pro $B$ gene cloned from one of these mutants.

We thank Dr I. Chibata, Dr T. Tosa and Dr T. Sato for encouragement.

\section{References}

ADAMS, E. \& FranK, L. (1980). Metabolism of proline and hydroxyproline. Annual Review of Biochemistry 49, 1005-1061.

BACHMANN, B. J. \& Low, K. B. (1980). Linkage map of Escherichia coli K-12, edition 6. Microbiological Reviews 44, 1-56.

BaICH, A. (1969). Proline synthesis in Escherichia coli. A prolineinhibitable glutamic acid kinase. Biochimica et Biophysica Acta 192, 462-467.

Bolivar, F., Rodriguez, R. L., Greene, P. J., Betlach, M. C., Heynecker, H. L., Boyer, H. W., Crosa, J. H. \& Falkow, S. (1977). Construction and characterization of new cloning vehicles. II. A multipurpose cloning system. Gene 2, 95-113.

BOYER, H. W. \& RoullaNd-DussoIx, D. (1969). A complementation analysis of the restriction and modification of DNA in Escherichia coli. Journal of Molecular Biology 41, 459-472.

Brosius, J. \& Holy, A. (1984). Regulation of ribosomal RNA promoters with a synthetic lac operator. Proceedings of the National Academy of Sciences of the United States of America 81, 6929-6933.

Cassan, M., Parsot, C., Cohen, G. N. \& Patte, J. C. (1986). Nucleotide sequence of $l y s C$ gene encoding the lysine-sensitive aspartokinase III of Escherichia coli K12. Journal of Biological Chemistry 261, 1052-1057.

Chen, N. Y., Hu, F. M. \& Paulus, H. (1987). Nucleotide sequence of the overlapping genes for the subunits of Bacillus subtilis aspartokinase II and their control regions. Journal of Biological Chemistry 262, 8787-8798.

Csonka, L. N., Gelvin, S. B., Goodner, B. W., Orser, C. S., SiemienaK, D. \& SLIGHTon, J. L. (1988). Nucleotide sequence of a mutation in the proB gene of Escherichia coli that confers proline overproduction and enhanced tolerance to osmotic stress. Gene 64, 199-205.

DANDEKAR, A. M. \& URATSU, S. L. (1988). A single base pair change in proline biosynthesis genes causes osmotic stress tolerance. Journal of Bacteriology 170, 5943-5945.

DAvis, B. D. \& Mingioli, E. S (1950). Mutants of Escherichia coli requiring methionine or vitamin $B_{12}$. Journal of Bacteriology $60,17-$ 28.

DAvis, R. W., Botstein, D. \& Roth, J. R. (1980). Advanced Bacterial Genetics. A Manual for Genetic Engineerinq. Cold Spring Harbor, NY: Cold Spring Harbor Laboratory.
De La Peña, P. \& Zasloff, M. (1987). Enhancement of mRNA nuclear transport by promoter elements. Cell 50, 613-619.

DeutCh, A. H., Rushlow, K. E. \& SMith, C. J. (1984). Analysis of the Escherichia coli proBA locus by DNA and protein sequencing. Nucleic Acids Research 12, 6337-6355.

DEVRIES, J. K. \& ZUBAY, G. (1967). DNA-directed peptide synthesis, II. The synthesis of the $\alpha$-fragment of the enzyme $\beta$-galactosidase. Proceedings of the National Academy of Sciences of the United States of America 57, 267-287.

Grothe, S., Krogsrud, R. L., McClellan, D. J., Milner, J. L. \& WoOD, J. M. (1986). Proline transport and osmotic stress response in Escherichia coli K-12. Journal of Bacteriology 166, 253-259.

HAWley, D. K. \& MCCluRE, W. R. (1983). Compilation and analysis of Escherichia coli promoter DNA sequences. Nucleic Acids Research 11, 2237-2255.

HAYZER, D. J. \& LeISINGER, T. (1980). The gene-enzyme relationships of proline biosynthesis in Escherichia coli. Journal of General Microbiology 118, 287-293.

HinNebusCh, A. G. \& Fink, G. R. (1983). Repeated DNA sequences upstream from $H I S 1$ also occur at several other co-regulated genes in Saccharomyces cerevisiae. Journal of Biological Chemistry 258, 52385247.

Katinka, M., Cossart, P., Sibilli, L., Saint-Girons, I., Chalvignac, M. A., Le Bras, G., Cohen, G. N. \& Yaniv, M. (1980). Nucleotide sequence of the thrA gene of Escherichia coli. Proceedings of the National Academy of Sciences of the United States of America 77, $5730-5733$.

LAEMmLI, U. K. (1970). Cleavage of structural proteins during the assembly of the head of bacteriophage T4. Nature, London 227, 680685.

Maniatis, T., Fritsch, E. F. \& Sambrook, J. (1982). Molecular Cloning: A Laboratory Manual. Cold Spring Harbor, NY: Cold Spring Harbor Laboratory.

Matsumoto, H., Hosogaya, S., Suzuki, K. \& Tazaki, T. (1975). Arginine gene cluster of Serratia marcescens. Japanese Journal of Microbiology 19, 35-44.

Miller, J. (1972). Experiments in Molecular Genetics. Cold Spring Harbor, NY: Cold Spring Harbor Laboratory.

NÜESCH, J. \& SCHÜMPERLI, D. (1984). Structural and functional organization of the gpt gene region of Escherichia coli. Gene 32, 243249.

Overbeeke, N., Bergmans, H., Van Mansfeld, F. \& Lugtenberg, B. (1983). Complete nucleotide sequence of $p h o E$, the structural gene for the phosphate limitation inducible outer membrane pore protein of Escherichia coli K12. Journal of Molecular Biology 163, 513-532.

Peoples, O. P., Liebl, W., Bodis, M., Maeng, P. J., Follettie, M. T., ARCHER, J. A. \& SinSKEY, A. J. (1988). Nucleotide sequence and fine structural analysis of the Corynebacterium glutamicum hom-thrB operon. Molecular Microbiology 2, 63-72.

RAFALSKI, J. A. \& FALCO, S. C. (1988). Structure of the yeast $\mathrm{HOM}_{3}$ gene which encodes aspartokinase. Journal of Biological Chemistry 263, 2146-2151.

ROSENBERG, M. \& COURT, D. (1979). Regulatory sequences involved in the promotion and termination of RNA transcription. Annual Review of Genetics 13, 319-353.

SANGer, F., Nicklen, S. \& Coulson, A. R. (1977). DNA sequencing with chain-terminating inhibitors. Proceedings of the National Academy of Sciences of the United States of America 74, 5463-5467.

Shapira, S. K., Chou, J., Richaud, F. V. \& Casadaban, M. J. (1983). New versatile plasmid vectors for expression of hybrid proteins coded by a cloned gene fused to $l a c Z$ gene sequences encoding an enzymatically active carboxy-terminal portion of $\beta$-galactosidase. Gene 25, 71-82.

Smith, C. J., Deutch, A. H. \& Rushlow, K. E. (1984). Purification and characteristics of a $\gamma$-glutamyl kinase involved in Escherichia coli proline biosynthesis. Journal of Bacteriology 157, 545-551.

Stocker, N. G., Fairweather, N. F. \& Spratt, B. G. (1982). Versatile low-copy-number plasmid vectors for cloning in Escherichia coli. Gene 18, 335-341.

Sugiura, M., Imai, Y., Takagi, T. \& Kisumi, M. (1985a). Improvement of a proline-producing strain of Serratia marcescens by subcloning of a mutant allele of the proline gene. Journal of Biotechnology 3, 47-58. 
Sugiura, M., TaKagi, T. \& Kisumi, M. (1985b). Proline production by regulatory mutants of Serratia marcescens. Applied Microbiology and Biotechnology 21, 213-219.

TAKAGI, T. \& KIsUmI, M. (1985). Isolation of a versatile Serratia marcescens mutant as a host and molecular cloning of the aspartase gene. Journal of Bacteriology 161, 1-6.

TAKagi. T., Imai. Y., Sugiura. M. \& Kisumi, M. (1985). Stability and instability of a cloned mutant allele of the proline gene in Serratia marcescens. Use of a mini- $F$ plasmid in the proline-overproducing mutant. Journal of Biotechnology 3, 59-71.
Takeshita, S., Sato. M., Toba, M., Masahashi, W. \& HashimotoGоTOH, T. (1987). High-copy-number and low-copy-number plasmid vectors for lac $Z$-complementation and chloramphenicol- or kanamycin-resistance selection. Gene 61, 63-74.

Yanisch-Perron, C., Vieira, J. \& Messing, J. (1985). Improved M13 phage cloning vectors and host strains: nucleotide sequences of the M13mp18 and pUC19 vectors. Gene 33, 103-119.

Zakin, M. M., Duchange, N., Ferrara, P. \& Cohen, G. N. (1983). Nucleotide sequence of the met $L$ gene of Escherichia coli. Journal of Biological Chemistry 258, 3028-3031. 